Introduction

\title{
EDITORS' INTRODUCTION SPECIAL EDITION OF CPCS
}

\section{Michael Townsley ${ }^{a}$, Lisa Tompson ${ }^{b}$ and Aiden Sidebottom}

${ }^{\text {a }}$ chool of Criminology and Criminal Justice, Griffith University, Qld, Australia bjill Dando Institute of Crime Science, University College London, London, UK

Correspondence: Michael Townsley, School of Criminology and Criminal Justice, Mt Gravatt Campus, Griffith University, Qld 4111, Australia. E-mail: m.townsley@griffith.edu.au

\begin{abstract}
This special edition of Crime Prevention and Community Safety: An International Journal comprises selected papers presented at the 15th Environmental Criminology and Crime Analysis (ECCA) seminar held at University College London, UK in July 2007. ECCA appears to be entering a new phase of growth, in terms of both participating members and research agenda. The 2007 seminar served as an international forum to discuss, exchange and reflect on the developments, research direction and advancements in environmental criminology and related areas such as situational crime prevention and offender profiling.
\end{abstract}

\section{Keywords}

environmental criminology; situational crime prevention; crime analysis

Crime Prevention and Community Safety (2008) 10, 69-74. doi:10.1057/cpcs.2008.1

\section{Environmental criminology}

\begin{abstract}
riminology is characterized as being a heterogeneous, multiorientated discipline, comprising numerous sub-strands (Ericson and Carriere, 1994). Within this eclectic body, environmental criminology focuses on the spatial and temporal distribution of offenders and offences (Bottoms, 2007). Crime is not randomly distributed, but rather concentrates on people, places and products (Sherman et al., 1989;
\end{abstract}


Clarke, 1999; Eck et al., 2007). This realization provides scope for understanding the factors and interactions that explain such variation. The tripod of theories underpinning environmental criminology offer insight into such patterning, namely routine activities theory (Cohen and Felson, 1979), rational choice theory (Cornish and Clarke, 1986) and crime pattern theory (Brantingham and Brantingham, 1993). Such approaches are considered well addressed and will not be expanded on here. Suffice it to say, collectively such approaches galvanized under the banner of environmental criminology have made significant contributions to the study and prevention of crime. The latter is of particular importance. Arguably more than other branches of criminology, environmental criminology possesses a more fluid interface between academic study and practical applications for crime and disorder reduction. In the UK for example, spatial and temporal analyses of crime are now a commonplace and effective element of operational policing. This stems partly from the close and productive relationship environmental criminology holds with situational crime prevention (SCP), given their mutual focus on place and its relation to crime. SCP holds that focus on crime rather than criminality can yield substantial crime reductions. This being achievable through manipulation of the environment to, among other things, increase the perceived effort, risk and reduce the reward available to offenders. Despite critics claiming situational approaches lavish disproportionate attention on property crime (Trasler, 1986), there is now a substantial body of cases which have utilized SCP principles to good effect on a gamut of diverse crime types (Homel and Clark, 1994; Wortley, 2001, 2002; Clarke and Newman, 2006; Wortley and Smallbone, 2006).

Recognition of the importance of environmental criminology has grown in recent years. This increased growth has brought with it increased diversification in the direction of study. Most notable have been attempts to uncover the spatio-temporal signatures of crime, and model ways to predict the prospective risk of certain crime types (Johnson et al., 2007). Furthermore, environmental criminology principles have been extended to the study of terrorism and terrorist-attack prevention (Clarke and Newman, 2006), obscene telephone calls (Clarke, 1992), utility of publicizing interventions (Smith et al., 2002, Johnson and Bowers, 2003) and credit card fraud (Masuda, 1993).

A typical feature of environmental criminology has been its willingness to borrow, sometimes wholesale, from sister disciplines such as behavioural geography, epidemiology and economics in the pursuit of understanding crime and criminal behaviour, with the ultimate intention of uncovering preventative solutions. Recent years have seen a noticeable shift however in the flow of findings, perhaps testament to the development and recognition of the field as a whole. There is now a catalogue of examples where environmental criminology has been used as a repository of concepts, tools and methods of use to other fields. A case in point is the application of optimal foraging theory and 
offender profiling models to the foraging patterns of pipistrelle bats, in Northeast Scotland (Le Comber et al., 2006).

\section{ECCA}

To facilitate greater collaboration and raise awareness of environmental criminology, an annual seminar was launched 15 years ago named "Environmental Criminology and Crime Analysis" (ECCA) to showcase exemplars of rigorous scientific research of relevance to reducing and preventing crime. In 2007 ECCA was hosted by the UCL Jill Dando Institute of Crime Science in London and sought to create a setting for researchers and end-users to communicate ideas and discuss issues on crime reduction. Recognition of its importance was reflected by the generosity of our sponsors, the UK Home Office Professional Standards Unit and Transport for London $(\mathrm{T} f \mathrm{~L})$.

Two developments were noteworthy in the 2007 ECCA meeting. First, early career researchers have become more prominent in recent years, but especially so during the 15th meeting. For instance, more than half the plenary sessions were delivered by researchers attending ECCA for either the first or second time. Second, the geographic range of participants has extended to countries typically under-represented in criminological research. Attendees from Israel, Turkey and Slovenia signify the growth that environmental criminology has already undergone, but also represent the scope for advancing environmental criminology to different places and different contexts. One suspects this trend is likely to increasingly figure in the environmental criminology literature, and equally be showcased at future ECCA seminars.

\section{Contents of the Special Issue}

This special issue is guest-edited by the present authors and organizers of ECCA 2007. The volume covers a wide range of topics from contributors drawn from numerous countries, we feel befitting of the range which characterized ECCA 2007.

This volume begins with a paper by Marie Skubak and David Kennedy who argue that focussed deterrence approaches to crime prevention - exemplified by the well-known Boston Gun Project (Kennedy et al., 1996) - share considerable theoretic overlap with SCP. By casting the former within the SCP framework, they claim additional insight and innovation will be a natural consequence. For instance, they provide a compelling argument that offending is often a group decision, yet conventional opportunity theories deal overwhelmingly with individual rationality. Bridging this disconnect will allow more effective interventions to be developed in a broad range of contexts. 
An offender's journey to crime, particularly the distance travelled, has been a long-standing avenue for environmental criminological research (see Rossmo, 2000). Here, Henk Elffers and colleagues model offender travel patterns in a more sophisticated manner than most journey to crime studies (which should probably be termed distance to crime). They explore the spatial interaction between where offenders live, where they offend and the journey between the two. They find little support for Stouffer's intervening opportunity thesis, that travel patterns are the product of opportunities available at a given location compared to those opportunities available at intervening locations, in terms of explaining offender travel movements. This is a surprising discovery in light that Stouffer's thesis enjoys considerable support for other human movement contexts.

A descriptive analysis of law enforcement seizures of clandestine methamphetamine laboratories is presented by Shukla and Bartgis. The noteworthy factor in their account is the introduction of legislation restricting access to a critical component required for the manufacture of methamphetamine. This opportunity reduction measure appears to have had a dramatic effect on the seizures of clandestine labs, although the authors point out the dangers of using measures of police activity to infer impact in illicit drug production.

The success and widespread adoption of the problem-oriented policing manual "Become a problem-solving crime analyst" (Clarke and Eck, 2003), has augmented the crime analysis triangle as a key reference point for practitioners analysing crime. The fourth paper in this journal provides detailed examination of a specific component of the crime analysis triangle, namely the concept of a place manager - those who have responsibility for controlling or influencing behaviour in a given place. In their study, Tamara Madensen and John Eck develop this component further through paying specific attention not just to the role of place manager, but also the process of place management. They examine the relationship and interactions between managers, managing, and violence in a series of bars in Cincinnati and propose a model that charts the effects of managerial decision-making on the levels of in-bar violence. Their research poses numerous implications, not least how managerial decisions may act as a source of opportunity for violence in the barroom setting.

The special edition concludes with an application of SCP principles to preventing terrorism in Turkey. Ekici, Ozkan, Celik and Maxfield provide a case study using the rating system outlined in Clarke and Newman's "Outsmarting the Terrorists" (2006), to assess the attractiveness of potential targets to terrorists. They also apply Clarke and Newman's proposed acronym EVIL DONE to a sample of critical places in Istanbul to imitate and explore the way terrorists may select a terrorism attack site. Their research suggests, perhaps counter to some conventional interpretations, that target selection may be influenced more by the immediate objective of the terrorist group, rather than any longterm group goals or group ideology. 


\section{References}

Bottoms, A.E. (2007). Place, Space, Crime and Disorder. In Maguire, M., Morgan, R. and Reiner, R. (eds) The Oxford Handbook of Criminology. 4th edn, Oxford: Oxford University Press, pp 528-574.

Brantingham, P.L. and Brantingham, P.J. (1993). Environment, Routine, and Situation: Toward a Pattern Theory of Crime. In Clarke, R.V. and Felson, M. (eds) Routine Activity and Rational Choice. New Brunswick: Transaction Publishers, pp 259-294.

Clarke, R.V. (1992). Deterring Obscene Phone Callers: The New Jersey Experience. In Clarke, R. V. (ed.) Situational Crime Prevention; Successful Case Studies. Albany, NY: Harrow and Heston.

Clarke, R.V. (1999). Hot Products: Understanding Anticipating and Reducing Demand for Stolen Goods, Police Research Series Paper 112. London: Home Office Policing and Reducing Crime Unit.

Clarke, R.V. and Eck, J. (2003). Become a Problem-Solving Crime Analyst: In 55 Small Steps. London: UCL Jill Dando Institute of Crime Science.

Clarke, R.V. and Newman, G.R. (2006). Outsmarting the Terrorists. London: Praeger Publishers.

Cohen, L.E. and Felson, M. (1979). Social Change and Crime Rate Trends: A Routine Activity Approach. American Sociological Review. Vol. 44, pp 588-608.

Cornish, D. and Clarke, R.V. (eds) (1986). The Reasoning Criminal. New York: SpringerVerlag.

Eck, J., Clarke, R.V. and Guerette, R. (2007). Risky Facilities: Crime Concentration in Homogeneous Sets of Facilities. In Farrell, G., Bowers, K., Johnson, S. and Townsley, M. (eds) Imagination for Crime Prevention: Essays in Honour of Ken Pease. Crime Prevention Studies, Vol. 21. Monsey, NY: Criminal Justice Press, pp 225-264.

Ericson, R.V. and Carriere, K. (1994). The Fragmentation of Criminology. In Nelken, D. (ed.) The Futures of Criminology. London: Sage.

Homel, R. and Clark, J. (1994). The Prediction and Prevention of Violence in Pubs and Clubs. In Clarke, R. V. (ed.) Crime Prevention Studies, Vol. 3. Monsey, NY: Criminal Justice Press, pp 1-46.

Johnson, S.D. and Bowers, K.J. (2003). Opportunity is in the Eye of the Beholder: The Role of Publicity in Crime Prevention. Criminology and Public Policy. Vol. 2, No. 3, pp 497-524.

Johnson, S.D., Bernasco, W., Bowers, K.J., Elffers, H., Ratcliffe, J., Rengert, G. and Townsley, M. (2007). Space-Time Patterns of Risk: A Cross National Assessment of Residential Burglary Victimization. Journal of Quantitative Criminology. Vol. 23, No. 3, pp 201-219.

Kennedy, D.M., Piehl, A.M. and Braga, A.A. (1996). Youth Violence in Boston: Gun Markets, Serious Youth Offenders, and a Use-Reduction Strategy. Law and Contemporary Problems. Vol. 59, No. 1, pp 147-196.

Le Comber, S.C., Nicholls, B., Rossmo, D.K. and Racey, P.A. (2006). Geographic Profiling and Animal Foraging. Journal of Theoretical Biology. Vol. 240, No. 2, pp 233-240.

Masuda, B. (1993). Credit Card Fraud Prevention: A Successful Retail Strategy. In Clarke, R.V. (ed.) Crime Prevention Studies. Vol. 1. Monsey, NY: Criminal Justice Press, pp 121-134.

Rossmo, K. (2000). Geographic Profiling. New York: CRC Press.

Sherman, L.W., Gartin, P.R. and Buerger, M.E. (1989). Hot Spots of Predatory Crime: Routine Activities and the Criminology of Place. Criminology. Vol. 27, No. 1, pp 27-55. 
Smith, M.J., Clarke, R.V. and Pease, K. (2002). Anticipatory Benefits in Crime Prevention. In Tilley, N. (ed.) Analysis for Prevention. Crime Prevention Studies, Vol. 13. Monsey, NY: Criminal Justice Press, pp 71-88.

Trasler, G. (1986). Situational Crime Prevention and Rational Choice: A Critique. In Heal, K. and Laycock, G. (eds) Situational Crime Prevention: From Theory into Practice. London: HMSO, pp 17-42.

Wortley, R. (2001). A Classification of Techniques for Controlling Situational Precipitators of Crime. Security Journal. Vol. 14, pp 63-82.

Wortley, R. (2002). Situational Prison Control: Crime Prevention in Correctional Institutions. Cambridge: Cambridge University Press.

Wortley, R. and Smallbone, S. (eds) (2006). Situational Prevention Of Child Sexual Abuse. Crime Prevention Studies, Vol. 19. Monsey, NY: Criminal Justice Press. 